DISTRIBUTION SHEET

\begin{tabular}{|c|c|c|c|c|c|}
\hline \multirow{2}{*}{$\begin{array}{l}\text { To } \\
\text { Analytical Services }\end{array}$} & \multirow{2}{*}{\multicolumn{3}{|c|}{$\begin{array}{l}\text { From } \\
\text { Characterization Support }\end{array}$}} & \multicolumn{2}{|c|}{ Page 1 of 1} \\
\hline & & & & \multicolumn{2}{|c|}{ Date $10-7-94$} \\
\hline \multirow{2}{*}{\multicolumn{4}{|c|}{$\begin{array}{l}\text { Project Title/Work Order } \\
\text { Tank 244A Tank Characterization Plan (WHC-SD-WM-TP-273) }\end{array}$}} & \multirow{2}{*}{\multicolumn{2}{|c|}{$\begin{array}{l}\text { EDT No. } 159077 \\
\text { ECN No. }\end{array}$}} \\
\hline & & & & & \\
\hline Name & $\underset{N}{M S I}$ & $\begin{array}{c}\text { Text } \\
\text { With } \\
\text { All } \\
\text { Attac } \\
\text { h. }\end{array}$ & $\begin{array}{l}\text { Text } \\
\text { Only }\end{array}$ & $\begin{array}{l}\text { Attach. } \\
\text { Append } \\
\text { ix } \\
\text { Only }\end{array}$ & $\begin{array}{c}\text { EDT/E } \\
\text { CN } \\
\text { Only }\end{array}$ \\
\hline
\end{tabular}

ONSITE

MACTEC

J. P. Haney

D. R. Lincoln

J. A. Sheriff

S7-73

$57-73$

B1-42

$x$
$x$
$x$

Pacific Northwest Laboratories

S. F. Bobrowski

K. L. Silvers

K7-28 $\quad x$

P7-22 $\quad X$

Westinghouse Hanford Company

J. W. Ba11

K. E. Bel1

J. L. Deichman

R. A. Dodd

S. J. Eberlein

D. W. Hamilton

K. K. Keller

J. M. Kier

J. G. Kristofzski

J. M. Jones

G. J. Miskho

P. M. Morant

R. D. Schreiber (10)

C. L. Thomas

T. C. Trible

Central Files.

O.S.T.I. (2)

H4-23

T6-06

H4-19

R2-70

S7-31

S7-03

S1-57

H4-19

T6-06

R2-70

S7-12

H4-19

R2-12

H4-19

S1-57

L8-04

โ8-07

$x$
$x$
$x$
$x$
$x$
$x$
$x$
$x$
$x$
$x$
$x$
$x$
$x$
$x$
$x$
$x$
$x$ 
2. To: (Receiving Organization) ANALYTICAL SERVICES

5. Proj./Prog./Dept./Div.: TWRS ENG/CHAR SUPPORT

8. Originator Remarks:

For original RELEASE
3. From: (Originating Organization) TWRS/CHARACTERIZATION SUPPORT

6. Cog. Engr.:

R. D. SCHREIBER

4. Related EDT No.

N/A

7. Purchase Order No.: $N / A$

9. Equip./Component No.:

$N / A$

10. System/Bldg./Facility: $2750 \mathrm{E} / 200 \mathrm{E}$

11. Receiver Remarks:

12. Major Assm. Dwg. No.: $N / A$

13. Permit/Permit Application No.: $N / A$

14. Required Response Date: $10-7-94$

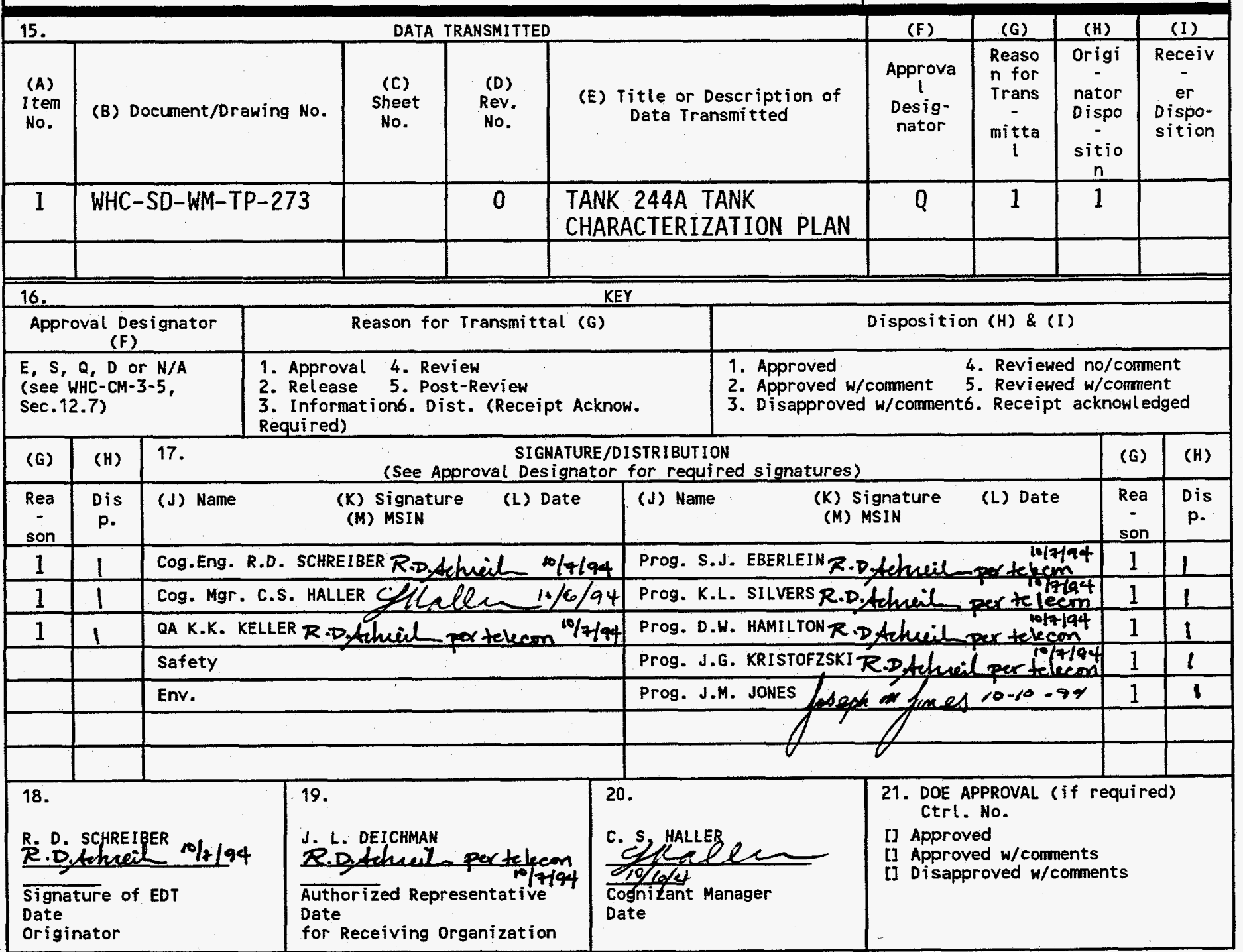

BD-7400-172-2 (04/94) GEF097 


\section{DISCLAIMER}

Portions of this document may be illegible in electronic image products. Images are produced from the best available original document. 


\section{RELEASE AUTHORIZATION}

Document Number: WHC-SD-WM-TP-273, REV 0

Document Title: TANK 244A TANK CHARACTERIZATION PLAN

Release Date: $10 / 10 / 94$

This document was reviewed following the procedures described in WHC-CM-3-4 and is:

APPROVED FOR PUBLIC RELEASE

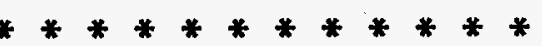

WHC Information Release Administration Specialist:
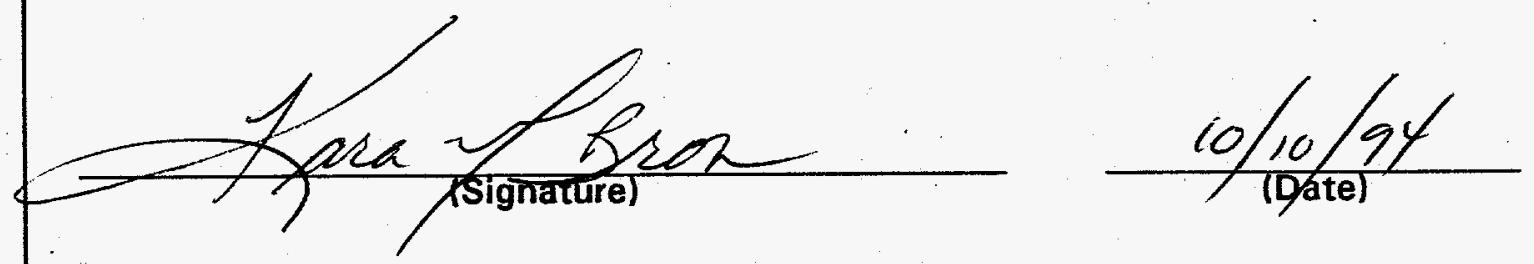
2. Title

TANK 244A TANK CHARACTERIZATION PLAN

\section{Key Words}

CHARACTERIZATION, COMPATIBILITY, QUALITY CONTROL, DOUBLE CONTAINED RECEIVER TANK, SAMPLING, ANALYSIS, TANK CHARACTERIZALJONSPAN PUBLIC RELEASE
3. Number

WHC-SD-WM-TP-273

4. Rev No.

6. Author

Name: R. D. SCHREIBER

R.P.Ahien $10 / 6 / 94$

Organization/Charge Code

$7 E 720 / N 4119$

\section{Abstract}

This document is a plan which serves as the contractual agreement between the Characterization. Program, Sampling Operations, WHC 222-S Laboratory, and PNL 325 Analytical Chemistry Laboratory. The scope of this $\mathrm{plan}$ is to provide guidance for the sampling and analys is of samples from tank $244 \mathrm{~A}$.

8. PuRpose AND USE OF DOCUMENT - This document was prepared for ase with in the U.S. Department of Energy and its contractors. $t$ is to be used onky to perform, direct, or integrato work under U.S. Department of Energy contracts. This document is not approved for public release until reviewed.

PATENT STATUS - This document sopy, since it is transmitted in advance of patent clearancer is made available in confidence solely for use in performante of work undec contracts with the U.S. Department of Energy. This document is not te be publ ished nor its contents atherwise disseminated or used for purposes other than specifjed above before patent approval for such release or use has been secured, upon request, from the Patent Counsel, U.S. Department of Energy Field Office, Richland, WA.

10.

RELEASE STAMP

DISCLAIMER - This report was prepared as an account of work sponsored by an agency of the United States Government. Neither the United States Government nor any agency thereof, nor any of their employees, nor any of their contractors, subcontractors or their employees, makes any warranty, express or implied, or assumes any legal liability or responsibility for the accuracy, completeness, or any third party's use or the results of such use of any information, apparatus, product, or process disclosed, or represents that its use would not infringe privately owned rights. Reference herein to any specific commercial product, process, or service by trade name, trademark, manufacturer, or otherwise, does not necessarily constitute or imply its endorsement, recommendation, or favoring by the United States Government or any agency thereof or its contractors or subcontractors. The views and opinions of authors expressed herein do not necessarily state or reflect those of the United States Government or any agency thereof.

9. Approval Designator $Q$

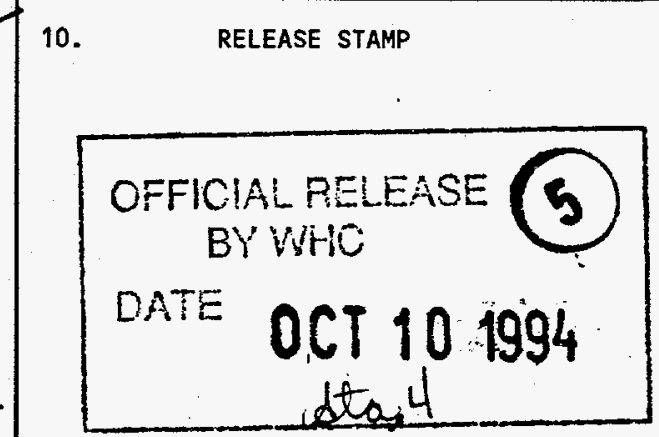


WHC-SD-WM-TP-273

Revision 0

\title{
Tank 244A Tank Characterization Plan
}

\author{
Prepared for the U.S. Department of Energy \\ office of Environmental Restoration \\ and Waste Management
}

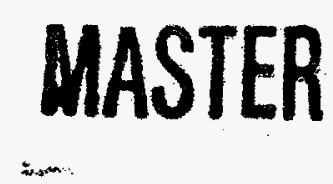

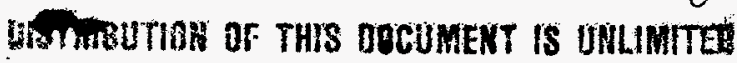

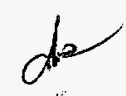


WHC-SD-WM-TP-273, REV. 0

CONTENTS

\section{SAMPLING EVENT A: LIQUID GRAB SAMPLING IN FISCAL YEAR 1994}

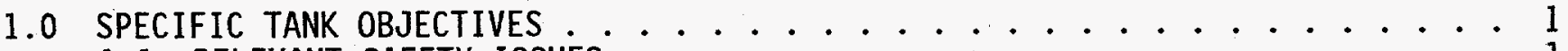

1.1 RELEVANT SAFETY ISSUES .................. 1

1.1.1 Tank 244A Characterization Objectives . . ..... 1

1.1.2 Waste Compatibility Program Data Quality Objective ..... I

2.0 TANK, WASTE, AND SAMPLING INFORMATION ............. 2

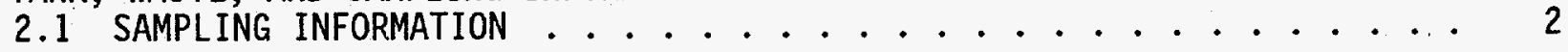

3.0 LABORATORY SAMPLE RECEIPT AND ANALYSIS INSTRUCTIONS .......... 2

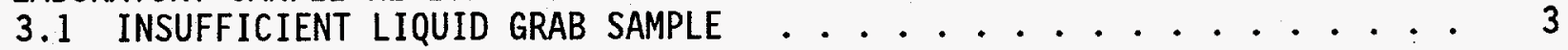

4.0 SPECIFIC ANALYTE, QUALITY CONTROL, AND DATA CRITERIA . . . . . . . 5

4.1 SPECIFIC METHODS AND ANALYSES ............... . . 5

4.2 QUALITY ASSURANCE/QUALITY CONTROL ............ 5

4.2.1 Laboratory Operations .............. . 5

4.2 .2 Sample Collection ................. 5

4.2 .3 Sample Custody ................ . 6

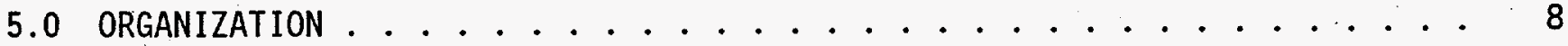

6.0 EXCEPTIONS AND PRIORITIES ..................... 8

6.1 EXCEPTIONS FOR TANK $244 A \ldots \ldots \ldots$

6.2 PRIORITIES FOR TANK $244 A \ldots \ldots$. . . . . . . . . 8

7.0 DELIVERABLES . . . . . . . . . . . . . . . . . . 9

7.1 FORMAT I REPORTING . . . . . . . . . . . . . . . . 9

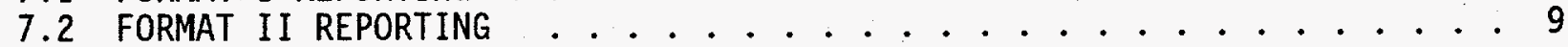

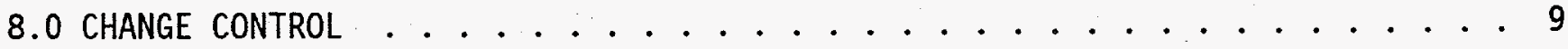

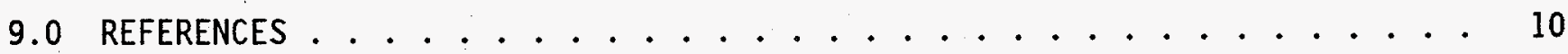


WHC-SD-WM-TP-273, REV. 0

LIST OF TABLES

Table 1 244A Grab Samples Chemical, Radiological, and Physical Analytical Requirements ............... 7

Table 2 Tank 244A Project Key Personnel List . . . . . . . . . . 8

LIST OF FIGURES

Figure 1 Test Plan Flowchart for Tank 244A .............. . 4

\section{LIST OF ABBREVIATIONS}

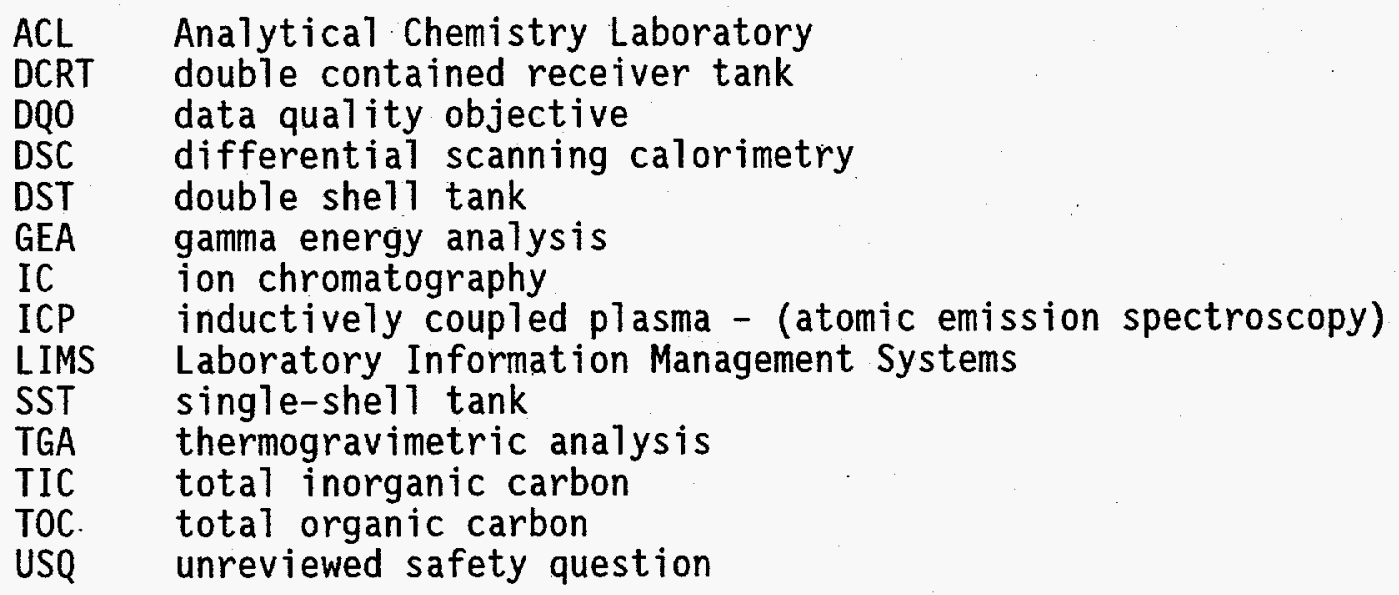


WHC-SD-WM-TP-273, REV. 0

\subsection{SPECIFIC TANK OBJECTIVES}

\subsection{RELEVANT SAFETY ISSUES}

The Double-She11 Tank (DST) System currently receives waste from the Single-Shell Tank (SST) System in support of SST stabilization efforts or from other on-site facilities which generate or store waste. Waste is also transferred between individual DSTs. The mixing or commingling of potentially incompatible waste types at the Hanford Site must be addressed prior to any waste transfers into the DSTs. The primary goal of the Waste Compatibility Program is to prevent the formation of an Unreviewed Safety Question (USQ) as a result of improper waste management.

Tank 244A is a Double Contained Receiver Tank (DCRT) which serves as an overflow tank for the East Area Tank Farms. Waste material is able to flow freely between the underground storage tanks and tank 244A. Therefore, it is necessary to test the waste in tank $244 \mathrm{~A}$ for compatibility purposes. Two issues related to the overall problem of waste compatibility must be evaluated:

- Assurance of continued operability during waste transfer and waste concentration.

- Assurance that safety problems are not created as a result of commingling wastes under interim storage.

The results of the grab sampling activity prescribed by this Tank Characterization Plan shall help determine the potential for four kinds of safety problems: criticality, flammable gas accumulation, energetics, and corrosion and leakage.

\subsubsection{Tank 244A Characterization Objectives}

The characterization effort applicable to this Tank Characterization Plan is focused on the resolution of the waste compatibility issue of tank 244A. Analyses shall be performed on the grab samples obtained from tank 244A. These analyses are discussed in section 4.0. Only decisions based on sampling and analysis of liquid waste from tank 244A will be addressed within this document; operational issues such as plugged pipelines and equipment problems are not within the scope of this Tank Characterization Plan.

\subsubsection{Waste Compatibility Program Data Quality Objective}

The document, Data Quality objectives for the Waste Compatibility Program (Carothers 1994) will be used in the generation of this Tank Characterization Plan. This document describes the process used to develop a data quality objective (DQO) for the waste compatibility issue, as well as the analytical requirements for determining waste compatibility. 


\subsection{TANK, WASTE, AND SAMPLING INFORMATION}

DCRT 244A is located in the A-farm complex and receives waste from several of the farms in the 200 East area. There are currently 7,260 gallons of liquid in tank $244 \mathrm{~A}$, which is suspected to be rainwater. However, since there is very limited access to the tank, it has never been sampled. Therefore, no historical information could be obtained. Further, as this is not one of the Hanford Site underground storage tanks, no fill history information is available.

\subsection{SAMPLING INFORMATION}

Tank $244 \mathrm{~A}$ is scheduled to be grab sampled. Two $100 \mathrm{~mL}$ samples shall be taken using the typical weighted-bottle sampler. The samples shall be taken from two different depths, preferrably one sample from the surface of the liquid and one from the bottom of the tank. For detailed information regarding the tank 244A grab sampling activities, refer to work package ES-94-00255. This work package wil1 contain a11 the applicable operating procedures and the chain of custody records for this sampling event.

With respect to sampling quality control, no field/trip blank shall be taken during this sampling event due to the order of magnitude of the analyte results expected. cross contamination should not have a significant effect on the analyte results (Sutey 1994).

\subsection{LABORATORY SAMPLE RECEIPT AND ANALYSIS INSTRUCTIONS}

A flowchart showing the general analysis scheme for tank $244 \mathrm{~A}$ is presented in Figure 1. These steps are given as guidance to the performing laboratory, and may be altered as necessary. Any alterations shall be documented, with justification, in the data report. Grab sample analyses may not need to be performed in the hot cell (based on radioactivity). If the samples must be analyzed in the hot cell, a hot cell blank should be performed by the laboratory, although it is not required; otherwise, no hot cell blank is necessary. The reporting levels for analyses are contained in Table 1 and are detailed in Section 7.0 of this document.

Any decisions or observations made during sample breakdown shall be documented in writing. These decisions and observations shall also be reported in the data report.

- Step 1 - Receive two liquid grab samples at the laboratory. The discussion of sample receipt is in Section 4.2.3, "Sample Custody" of this document.

- Step 2 - Record visual observations such as color and clarity of the liquid, and the presence of any solid particles.

- Step 3-Closely inspect the 1 iquid sample for the presence and approximate volume of any solids. If no solids exist, proceed to Step 5. However, if solids are recovered from the liquid, go to Step $4 A$.

- Step $4 A$ - Remove a portion of the liquid sample and determine the volume percent solids by centrifugation. 
WHC-SD-WM-TP-273, REV. 0

- Step 4B - If greater than 1 gram of solid sample is recovered, archive these solids for possible future analyses (Bratzel 1994).

- Step 5-Closely inspect the liquid sample for the presence and approximate volume of any potential organic layers. If no potential organic layers exist, proceed to Step 7. However, if potential organic layers exist, go to Step 6.

- Step 6-Report any visual potential organic layer as soon as possible by Format I reporting. Separate and retain the potential organic layer in a jar. Perform the following steps on the remaining (possibly aqueous) layer.

- Step 7 - Remove sufficient aliquots and then perform those analyses shown in Table 1 .

- Step 8 - Archive up to $40 \mathrm{~mL}$ of the remaining liquid sample (Bratzel 1994).

\subsection{INSUFFICIENT LIQUID GRAB SAMPLE}

In the event that the sample volume from tank $244 \mathrm{~A}$ is found to be insufficient to perform the requested analyses in Table 1, Characterization Support and Analytical Services shall be notified (for points of contact, see Section 5.0, Table 2). A prioritization of the analyses required in this Tank Characterization Plan is given in Section 6.2. Any analyses prescribed by this document, but not performed, shall be identified and justified in the appropriate data report. 
WHC-SD-WM-TP-273, REV. 0

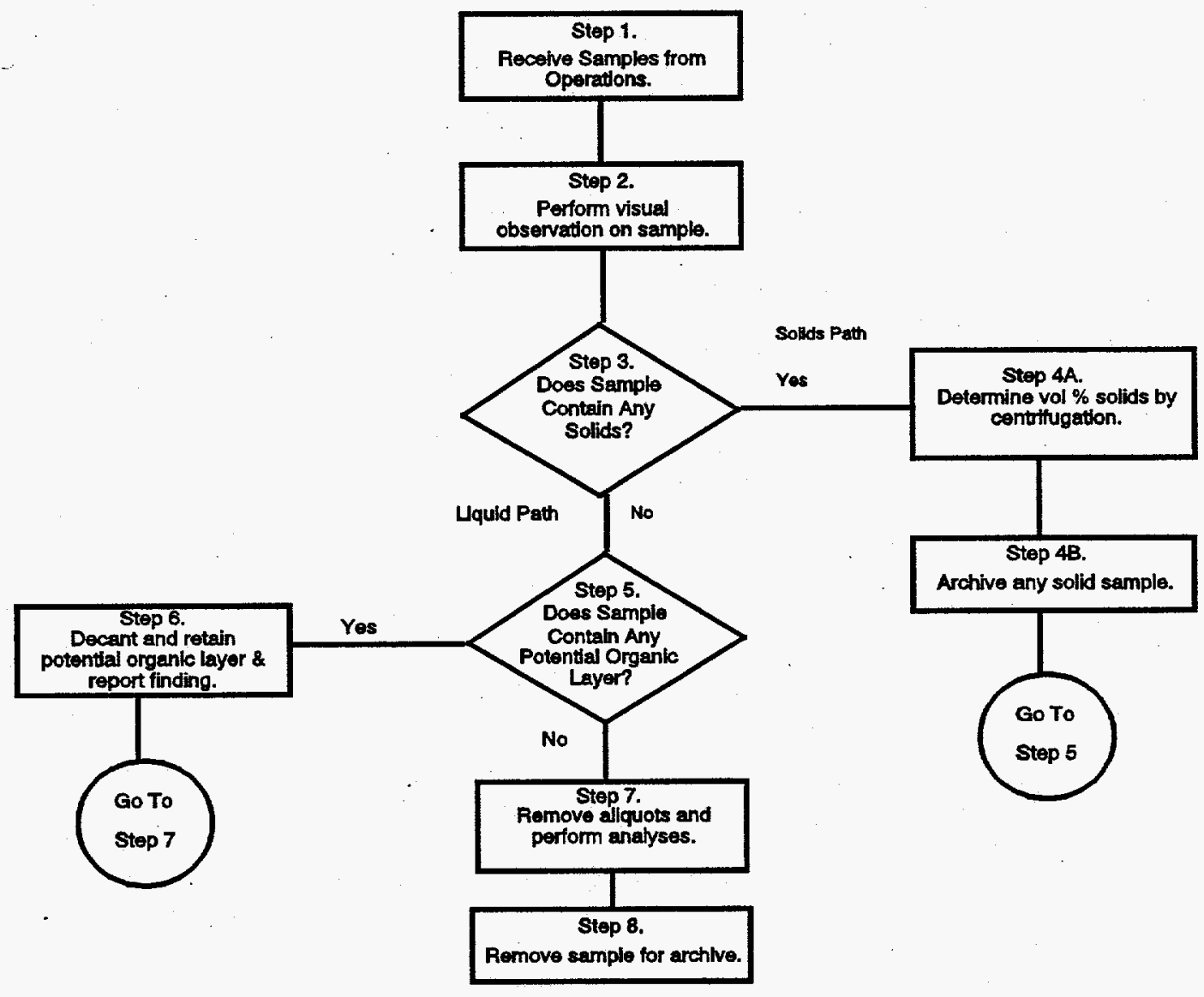

Figure 1: Test Plan Flowchart for Tank 244A 
WHC-SD-WM-TP-273, REV. 0

\subsection{SPECIFIC ANALYTE, QUALITY CONTROL, AND DATA CRITERIA}

\subsection{SPECIFIC METHODS AND ANALYSES}

Table 1 summarizes the analyses to be performed on the tank $244 \mathrm{~A}$ grab samples. The laboratory procedure numbers which shall be used in the analyses are included in the table. These analyses are based on the Waste Compatibility Program's DQO (Carothers 1994).

\subsection{QUALITY ASSURANCE/QUALITY CONTROL}

\subsubsection{Laboratory Operations}

The 222-S Laboratory has a quàlity assurance program plan (Meznarich 1994) and a quality assurance project plan (Taylor 1993) that shall provide the primary direction for the quality assurance/quality control involved in analyzing the 244A tank waste samples. If the analyses are performed at the $325 \mathrm{ACL}$, the analys is shall be guided by the 325 Quality Assurance Plan (Kuhl-Klinger 1994). Additionally, the Hanford Analytical Services Quality Assurance P7an. (DOE 1994), when implemented, shall be used as quality assurance/quality control guidance.

Method specific quality control such as calibrations and blanks are also found in the analytical procedures. Sample quality control (duplicates, spikes, standards) are identified in Table 1. If no criteria are provided in Table 1 , the performing laboratory shall perform to its quality assurance plan(s).

\subsubsection{Sample Collection}

Two grab samples from tank $244 \mathrm{~A}$ are to be taken and shipped to the laboratory by Sampling Operations in accordance with work package ES-94-00255. That work package shall initiate the chain-of-custody for the samples. The following documents will be used as guidance in the handling and shipment of the tank 244A Tiquid grab samples:

- T0-100-052, "Segregate, Package, and Inventory Radioactive Waste."

- WHC-CM-2-14, "Responsibilities and Procedures for all Hazardous Material Shipments."

- WHC-SD-TP-SARP-001, "Sample Pig Transport System Safety Analysis Report for Packaging (onsite)."

- WHC-SD-WM-HSP-002, "Tank Farm Health and Safety P7an."

Samples shall be identified by a unique number before being shipped to the laboratory. The sampling team is responsible for documenting any problems and procedural changes affecting the validity of the sample in a field notebook. Sampling Operations shall enter this information in the comment section of the chain-of-custody form for addition to the data reports.

Sampling Operations should transport each sample collected to the performing laboratory within 1 working day of removing the sample from tank $244 \mathrm{~A}$, but must 
transport each sample within 3 working days. Sampling Operations is responsible for verbally not ifying the laboratory (373-2435 for 222-S Laboratory; 373-6704 for $325 \mathrm{ACL}$ ) at least 24 hours ( 72 hours for $325 \mathrm{ACL}$ ) in advance of an expected shipment. If samples are going to be delivered after 3:00 pm, the laboratory shall be notified at least four hours in advance of actual sample shipment so that proper shift operations can be planned.

\subsubsection{Sample Custody}

The chain-of-custody form is initiated by the sampling team as described in the work package. Grab samples are shipped in a bottle and sealed with a Waste Tank Sample Seal. All sample shipments are to be labeled with the following information:

WASTE TANK SAMPLE SEAL

Supervisor

Date of Sampling

Shipment No.
Sample No.

Time of Sampling

Serial No.

The sealed and labeled samples are shipped to the laboratory along with the chain-of-custody form. The receipt and control of samples in the Westinghouse Hanford 222-S Laboratory is described in procedure L0-090-101. Receipt and control of samples in the $325 \mathrm{ACL}$ is described in procedure PNL-ALO-051. 


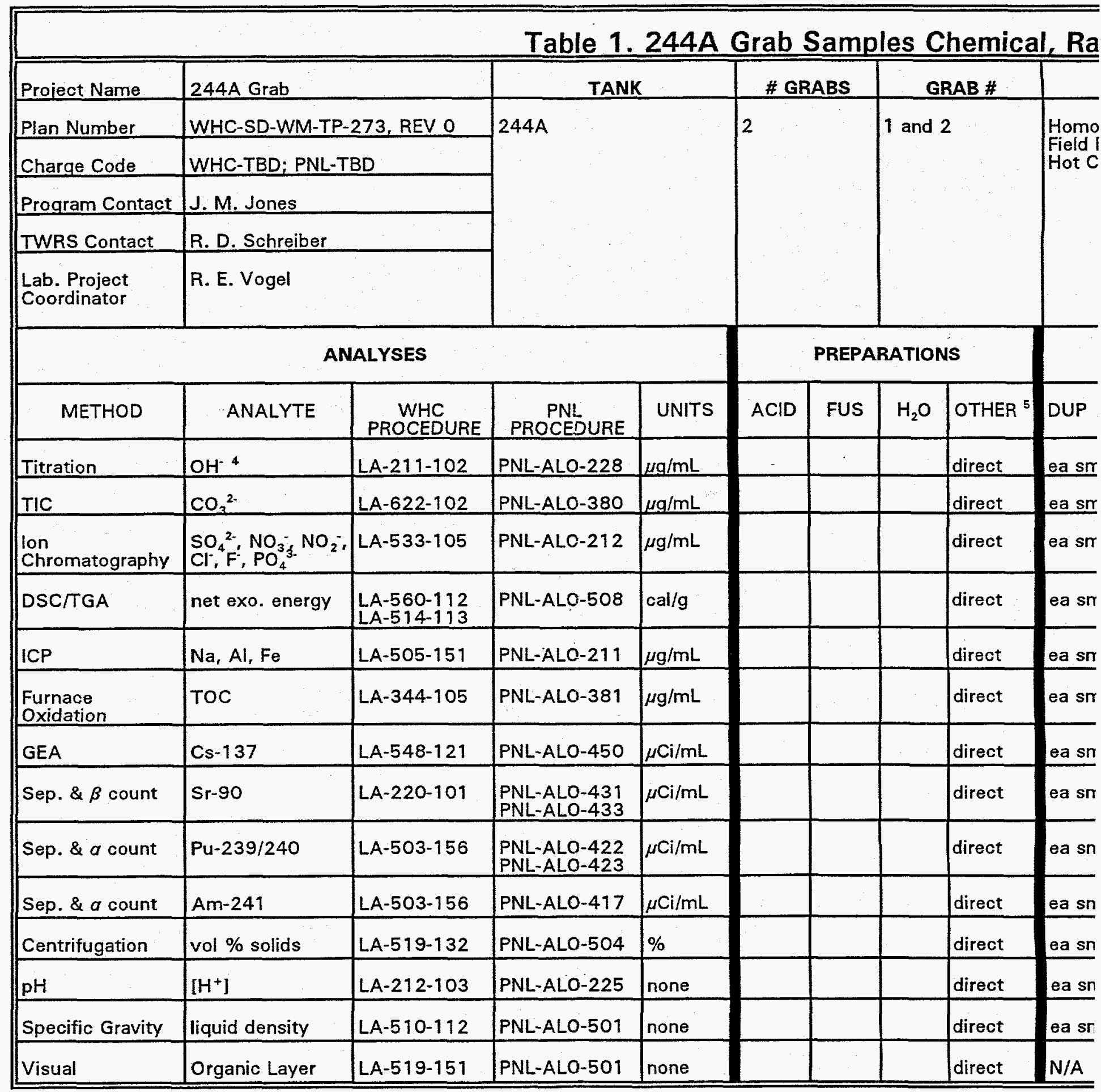

ea - each, DUP - duplicate, spk/msd - spike or matrix spike duplicate, AB - analytical batch, N/A - not applicablı Serial dilutions rather than matrix spikes may be performed to assess accuracy.

Tracer or carrier may be used in place of a spike and results corrected for recovery.

$\mathrm{OH}$ - will not be run if $\mathrm{pH}<12.5$.

Direct liquid samples will be diluted in acid or water to adjust to proper sample size.

Action limit is applicable up to $500^{\circ} \mathrm{C}$. If the energetics action limit is exceeded, laboratory personnel and We: See Section 6.1. 


\section{ological and Physical Analytical Requirements}

COMMENTS

nization Test - Not Required

nk - Not Required

Blank - Not Required

\begin{tabular}{|l|l} 
& REPORTING LF \\
\hline FORMAT I & PORMT II \\
\hline FORMAT & \\
\hline FORMAT III & \\
\hline FORMAT IV & \\
\hline FORMAT V & \\
\hline FORMAT VI & \\
\hline
\end{tabular}

LEVELS

Early Notify

Process Control

Safety Screen

Waste Management

RCRA Compliance

Special

\begin{tabular}{|c|c|c|c|c|}
\hline \multicolumn{4}{|c|}{ CRITERIA } & \multirow{2}{*}{$\begin{array}{l}\text { REPORT } \\
\text { FORMAT }\end{array}$} \\
\hline $\begin{array}{l}\text { PRECI } \\
\text { SION }\end{array}$ & ACCURCY ${ }^{7}$ & $\begin{array}{l}\text { NOTIFICATION } \\
\text { LIMIT }\end{array}$ & $\begin{array}{l}\text { EXPECTED } \\
\text { RANGE }\end{array}$ & \\
\hline $\pm 20 \%$ & $80-120 \%$ & {$\left[\mathrm{OH}^{-}\right] \leq 0.01 \mathrm{M}$ or $\geq 8 \mathrm{M}$} & not available & 1,11 \\
\hline $\pm 20 \%$ & $80-120 \%$ & none & not available & II \\
\hline $\pm 20 \%$ & $80-120 \%$ & $\begin{array}{l}{\left[\mathrm{NO}_{3}{ }^{-}\right] \leq 506 \text { or } \geq 253,000 ;} \\
{\left[\mathrm{NO}^{3-}\right] \geq 52000(\mu \mathrm{g} / \mathrm{mL})}\end{array}$ & not available & I, 11 \\
\hline $\pm 20 \%$ & $80-120 \%$ & net exo. energy $>0^{6}$ & not available & 1,11 \\
\hline $\pm 20 \%$ & $80-120 \%$ & none & not available & II \\
\hline $\pm 20 \%$ & $80-120 \%$ & $>10,000 \mu \mathrm{g} / \mathrm{mL}$ & not available & 1,11 \\
\hline $\pm 20 \%$ & $80-120 \%$ & none & not available & II \\
\hline $\pm 20 \%$ & $80-120 \%$ & none & not available & II \\
\hline $\pm 20 \%$ & $80-120 \%$ & $>0.8 \mu \mathrm{Ci} / \mathrm{mL}$ & not available & 1,11 \\
\hline $\pm 20 \%$ & $80-120 \%$ & $>0.1 \mu \mathrm{Ci} / \mathrm{g}$ & not available & 1,11 \\
\hline $\pm 20 \%$ & $80-120 \%$ & none & not available & II \\
\hline $\pm 20 \%$ & $80-120 \%$ & none & not available & $\|$ \\
\hline $\pm 20 \%$ & $80-120 \%$ & $>1.3$ & not available & I, II \\
\hline N/A & N/A & none & not available & $1, I I$ \\
\hline
\end{tabular}

ntrx - matrix.

Systems Engineering will decide if adiabatic calorimetry shall be performed. 
WHC-SD-WM-TP-273, REV. 0

\subsection{ORGANIZATION}

The organization and responsibility of key personnel involved in this tank $244 \mathrm{~A}$ characterization project are listed in Table 2.

Table 2: Tank 244A Project Key Personnel List.

\begin{tabular}{|c|c|c|}
\hline Individual & Organization & Responsibility \\
\hline $\begin{array}{l}\text { J. G. } \\
\text { Kristofzski }\end{array}$ & $\begin{array}{c}222-S \text { Analytical } \\
\text { Operations }\end{array}$ & $\begin{array}{c}\text { Program Support Manager of } \\
\text { Analytical Operations }\end{array}$ \\
\hline K. L. SiTvers & $\begin{array}{c}325 \text { Analytical Chemistry } \\
\text { Laboratory }\end{array}$ & $\begin{array}{l}\text { Project Manager for Single Shell } \\
\text { Tank (Grab Sampling) Projects }\end{array}$ \\
\hline R. D. Schreiber & $\begin{array}{c}\text { TWRS Characterization } \\
\text { Support }\end{array}$ & $\begin{array}{c}\text { Tank 244A Tank Characterization } \\
\text { Plan Cognizant Engineer }\end{array}$ \\
\hline J. M. Jones & East Systems Engineering & $\begin{array}{c}\text { Sampling and Compatibility } \\
\text { Cognizant Engineer } \\
\end{array}$ \\
\hline J. L. Deichman & Analytical Services & $\begin{array}{c}\text { Manager of Analytical Services } \\
\text { Program Management and } \\
\text { Integration }\end{array}$ \\
\hline $\begin{array}{c}\text { East Tank Farm } \\
\text { Operations. Shift } \\
\text { Manager } \\
\end{array}$ & Tank Farm Operations & $\begin{array}{l}200 \text { East Tank Farm Point of } \\
\text { Contact if Action Limit is } \\
\text { Exceeded }(372-2689)\end{array}$ \\
\hline
\end{tabular}

\subsection{EXCEPTIONS AND PRIORITIES}

\subsection{EXCEPTIONS FOR TANK 244A}

In the Waste Compatibility DQO, several necessary specifications concerning sampling and analysis were omitted. These clarifications are addressed in (Sutey 1994).

In (Sutey 1994), accuracy requirements are specified-in terms of spike recovery. However, the laboratory can also assess accuracy via standards. Therefore, it was presumed that the Program would 1 ike to have information on accuracy for those analyses for which spikes are not performed, and would specify accuracy requirements as $80-120 \%$ regardless of the method of accuracy determination (Table 1).

Since historical information exists to adequately address the potential for line plugging and precipitation of solids during the transfer of waste, no viscosity and cooling curve analyses shall be require during this analysis activity (Jones 1994).

\subsection{PRIORITIES FOR TANK 244A}

In order to complete the compatibility assessment for tank $244 \mathrm{~A}$, results from all of the analyses in Table 1 must be received. Therefore, if insufficient sample is 
retrieved, the tank shall need to be resampled at a later date. However, analyses are still requested on any sample obtained, and should be performed in the following order:

(1) Corrosion Species: $\mathrm{OH}^{-}, \mathrm{IC}$, and $\mathrm{pH}$

(2) Energetics: DSC/TGA and separable organic layer

(3) Flammable Gas Accumulation: SpG

(4) Criticality Analyses: Pu-239/240, Am-241, ICP, and volume percent solids

(5) TOC

(6) Heat Generation: $\mathrm{Sr}-90$ and $\mathrm{Cs}-137$

(7) Other analyses 1 isted in Table 1

\subsection{DELIVERABLES}

A11 analyses of tank $244 \mathrm{~A}$ waste material will be reported as Formats I and II as shown in Table 1. The Waste Compatibility Program may request progress reports from the laboratory regarding the analyses via this Tank Characterization Plan. However, due to the rapid turn around time required for the 244A analyses (see Section 7.2), no special progress reports sha11 be required from the laboratory. Al1 reports generated as part of normal operations (e.g., monthly reports) shall still be done. The data shall be reported in the units given by Table 1 , and all procedure and revision numbers used in the analyses shall be included in the report. Additional information regarding reporting formats is given in (Schreiber 1994a).

\subsection{FORMAT I REPORTING}

Table 1 contains the notification limits for each analyte. Any results that exceed the notification Timits defined in the DQO processes shall be reported immediately by calling the East Tank Farm Operations Shift Manager at 372-2689 and the Characterization Program office (Schreiber 1994b). This verbal notification must be followed within 1 working day by written communication to J. M. Jones, J. L. Deichman, R. D. Schreiber, D. R. Bratzel, T. J. Kelley, S. J. Eberlein, and N. W. Kirch, documenting the observations. Additional analyses for verification purposes may be contracted between the performing laboratory and the contacts above either by a revision to this document or by letter of instruction.

\subsection{FORMAT II REPORTING}

Due to the immediate necessity of the data, the 222-S Laboratory has agreed to have the analysis completed and results reported within 60 days of receipt of the sample at the laboratory loading dock. If the samples must be sent to $325 \mathrm{ACL}$, the results shall be reported within 90 days of receipt of the last sample from tank $244 \mathrm{~A}$ by the 7aboratory. The results will be reported using either a Laboratory Information Management Systems (LIMS) report or electronically to J. M. Jones. In addition to the LIMS/electronic report, a letter report shall be sent to R. D. Schreiber, L. M. Sasaki, J. M. Jones, P. Sathyanarayana, S. J. Eberlein, and D. R. Bratzel summarizing the results. Any observations taken during the receipt and analysis of the grab samples should be included in this letter report.

\subsection{CHANGE CONTROL}

Under certain circumstances, it may become necessary for the performing 1 aboratory to make decisions concerning a sample without review of the data by the customer or the 
WHC-SD-WM-TP-273, REV. 0

Characterization Program. These changes shall be documented. Changes may be documented through the use of internal characterization changes notices or analytical deviation reports for minor low-impact changes and documented in applicable laboratory notebooks. All significant changes (such as changes in scope) shall be documented by Characterization Support via an Engineering Change Notice to this Tank Characterization Plan. All changes shall also be clearly documented in the final data report.

Additional analysis of grab sample material from this characterization project at the request of the Characterization Program shall be performed according to a revision of this Tank Characterization Plan.

\subsection{REFERENCES}

Bell, K. E., et al., 1994, Tank Waste Remediation System Tank Waste Analysis Plan, WHC-SD-WM-PLN-077, Rev. 0, Westinghouse Hanford Company, Richland, Washington.

Bratze], D. R., Letter to S. M. Joyce, "Archiving Requirements", 7E720-94-125, dated June $23,1994$.

Carothers, K. G., 1994, Data Quality Objectives for the Waste Compatibility Program, WHC-SD-WM-DQO-001, Westinghouse Hanford Company, Richland, Washington.

DOE, 1994, Hanford Analytical Services Quality Assurance P7an, DOE/RL-94-55, Rev. 0, U. S. Department of Energy, Richland Field Office, Richland, Washington.

Jones, J. M., cc:Mail to R. D. Schreiber, "Viscosity and Cooling Curves", dated June $10,1994$.

Kuhl-K1 inger, K. J., 1994, Quality Assurance P7an for Activity Conducted by the Analytical Chemistry Laboratory (ACL), MCS-003, Rev. 1, Pacific Northwest Laboratory, Richland, Washington.

Meznarich, H. K., 1994, Quality Assurance Program Plan for Laboratory Analysis and Process Testing, WHC-SD-CP-QAPP-003, Rev. 1, Westinghouse Hanford Company, Richland, Washington.

Schreiber, R. D., 1994, Letter to C. S. Haller, "Revised Interim Tank Characterization Plan Guidance", 7E720-94-121, dated May 13, 1994.

Sutey, M. J., 1994, Letter to C. DeFigh-Price, "Precision and Accuracy Requirements for the Waste Compatibility Data Quality objectives (DQO), WHC-SD-WM-DQO-001", 7CF30-94-023, dated June 3, 1994.

Taylor, L.H., 1993, Quality Assurance Project Plan for Chemical Analysis of Highly Radioactive Mixed Waste Samples in Support of Environmental Activities on the Hanford Site, WHC-SD-CP-QAPP-002 Rev. OA, Westinghouse Hanford Company, Rich7and, Washington.

Whelan, T. E., 1994, Tank Waste Remediation System Quality Assurance Program P7an, WHC-SD-WM-QAPP-025, Rev. 0, Westinghouse Hanford Company, Richland, Washington. 